\title{
Not all firms react the same to exchange rate volatility? A firm level study
}

\author{
Cengiz Tunc $^{\mathrm{a}, *}$, M. Nihat Solakoglu ${ }^{\mathrm{b}}$ \\ ${ }^{a}$ Department of Economics, Toros University, Mersin, Turkey \\ ${ }^{\mathrm{b}}$ Department of Banking \& Finance, Bilkent University, Ankara, Turkey
}

\section{A R T I C L E I N F O}

\section{JEL Classification:}

F14

F31

F41

\section{Keywords:}

Exchange rate volatility

Exports

Firm level estimation

\begin{abstract}
A B S T R A $\mathrm{T}$
This article investigates the effect of exchange rate volatility on the exporting behavior of firms using a very rich Turkish firm-level data for the period of 1989-2013. The estimation results show that although exchange rate volatility has depressing impact on foreign sale share of firms, the magnitude and the sign of the effect differ substantially across firm classifications. More specifically, medium-sized firms, firms not listed in the stock market, and less foreign market dependent firms observe significant depressing impact of exchange rate volatility while the other firms are, by and large, immune to negative effect of exchange rate volatility. Furthermore sectors and firm age have important role on the differential impact of exchange rate volatility on foreign sales activity of firms.
\end{abstract}

\section{Introduction}

For the last forty years, the effect of exchange rate uncertainty on international trade has been intensively investigated in the literature as both real and nominal exchange rates have displayed periods of significant volatility since the collapse of the Bretton Woods system. However, there is no consensus in the literature about the exact effect of exchange rate uncertainty in terms of direction and magnitude on the flow of international trade. On the one hand, a large number of studies claim that an increase in exchange rate volatility has a depressing impact on international trade because of the costs associated with increases in exchange rate risk. At the same time, some other studies have concluded either an ambiguous or positive effect of exchange rate volatility on international trade as the effect depends on such factors as hedging and option opportunities, the degree of risk aversion, and the currency denomination of contract. $^{1}$

The contradiction in the results on the effect of exchange rate volatility on international trade has encouraged researchers to use micro-level data, because trade activity of a country is the sum of trade activity of individual firms and because there are important advantages of using micro-data over aggregate data. First, aggregate data could mask the potential differential effects of exchange rate volatility on firms with different attributes. Micro-data analyses on the international trade effect of exchange rate volatility provide insights into heterogeneous responses across firms with different characteristics such as size, foreign sales intensity, maturity of firms, and stock market status. Second, micro-data eliminates possible measurement errors that could appear in aggregate data and in constructing aggregate indices. Third, the use of micro-data alleviates possible reverse causality from trade to exchange rate volatility.

In this paper, we study the effect of exchange rate volatility on export behavior of firms for a small open economy, Turkey. Our

\footnotetext{
* Corresponding author.

E-mail addresses: cengiz.tunc@toros.edu.tr (C. Tunc), nsolakoglu@bilkent.edu.tr (M.N. Solakoglu).

1 See McKenzei (1999) and Bahmani-Oskooee and Hegerty (2007) for review of the literature on exchange rate volatility and international trade.
} 
empirical estimation relies on a large panel of Turkish firms for the period of 1989-2013. This unique dataset has some important merits for the analysis of exchange rate pass-through on firms' foreign sales. First, this long dataset captures many periods of high and low levels of volatility in exchange rates. Second, the dataset covers a fairly rich heterogeneity of firms, reflecting the firm composition of a country with a typical small open economy. Firms with different sizes, in different sectors, and stock market status are all included in the dataset. Therefore, we are able to examine in particular the differential effects of the volatility on firms' foreign sales conditional on such firm characteristics as dependency on foreign markets, size, stock market status, and age.

The results of this study show that once standard macroeconomic variables are controlled, the effect of exchange rate volatility on the foreign sale share of an average firm is negative with a one standard deviation increase in the volatility would decrease an average firm's foreign sale share by 13 percent. This baseline result indicates that a high level of uncertainty captured by exchange rate volatility has on average a large depressing effect on the foreign sale share of a typical Turkish firm. However, the magnitude and even the sign of the effect changes depending on firm characteristics. For instance, medium- and large-sized firms are exposed more to exchange rate volatility than smaller firms. A further important finding of the study is that exchange rate volatility has no significant impact on the foreign sale shares of more dependent firms, (firms with a share of foreign sales larger than $50 \%$ of total sales) which could be attributed to the possibility that these firms use hedging or other instruments to prevent the negative impact of exchange rate volatility. The results also show that foreign sale shares of firms in the stock market are not affected by exchange rate volatility. This finding should not be surprising as firms that are listed in the stock market are large and similar to more dependent firms are expected to have necessary tools to prevent the negative effects of exchange rate volatility on their foreign business activities. Furthermore, firms in the stock market are more transparent and are usually not expected to take uncalculated risk.

These results provide some policy implications as well. One clear point is that exchange rate volatility has a depressing impact on foreign sale share of an average Turkish firm. Therefore, if policy makers wish to promote export, they should put emphasis on exchange rate stability while avoiding and reducing circumstances that could generate volatility in the exchange rate. However, as the results further suggest, not all firms are equally exposed to exchange rate volatility. While the volatility has a depressing impact on the foreign sale share of some firms, other firms are immune to such volatility. Therefore, policy makers should also take into consideration the heterogeneous response of firms to exchange rate volatility when designing any policy measure to promote export. Hence, the use of hedging tools should be encouraged for firms, in particular for smaller firms, by increasing the availability of tools, improving access and reducing costs.

\section{Literature review}

The effect of exchange rate volatility on the exporting behavior of firms has been widely discussed in the literature from both a theoretical and an empirical perspective. However, no clear consensus has been reached about the exact effect of exchange rate volatility on trade. On the one hand, many theoretical studies and empirical aggregate-level studies for different countries or country groups and different time periods have concluded that an increase in exchange rate volatility increases uncertainty and that trade cost discourages especially more risk averse firms from international trade (Ethier (1973), Clark (1973), Hooper and Kohlhagen (1978), Cushman (1983), Kenen and Rodrik (1986), Chowdhury (1993), Arize (1996), Rahman and Serletis (2009), Chit, Rizov, and Willenbockel (2010), Ethier (1973), Clark (1973), Hooper and Kohlhagen (1978), Cushman (1983), Kenen and Rodrik (1986), Chowdhury (1993), Arize (1996) Rahman and Serletis (2009), Chit et al. (2010)). On the other hand, other studieGs have concluded that the effect of exchange rate volatility has a neutral (Bailey, Tavlas, and Ulan (1986), Grauwe (1988), Sercu and Vanhulle (1992), Gagnon (1993), Sauer and Bohara (2001), Barkoulas, Baum, and Caglayan (2002), Clark, Natalia Tamirisa, Sadikov, and Zend (2004), Tenreyno (2007), Bailey et al. (1986), Grauwe (1988), Sercu and Vanhulle (1992), Gagnon (1993), Sauer and Bohara (2001), Barkoulas et al. (2002), Clark et al. (2004), and Tenreyno (2007)) or even a positive (Klein (1990), Franke (1991), Broll and Eckwert (1999), Klein (1990), Franke (1991), Broll and Eckwert (1999)) effect on international trade.

This disagreement in the literature leads to questioning the studies that use aggregate data, because these studies are subject to problems such as aggregation bias, reverse causality from international trade to exchange rate movements, and measurement errors in the aggregation process and in generating aggregate indices. Therefore, in recent years, with the availability of more data, we have observed studies using firm-level data when examining the effect of exchange rate volatility on trade (Cheung and Sengupta (2013), Hericourt and Poncet (2013), Solakoglu, Solakoglu, and Demirag (2008), Greenaway, Kneller, and Zhang (2010), Cheung and Sengupta (2013), Hericourt and Poncet (2013), Solakoglu et al. (2008), Greenaway et al. (2010)). While in these studies, exchange rate uncertainty is found to have a depressing impact on a typical firm's foreign sales, not only the magnitude but also the sign of the effect depends on a firm's characteristics. Cheung and Sengupta (2013) find that firms that have a smaller export share are more exposed to exchange rate volatility. According to Hericourt and Poncet (2013), Dekle and Ryoo (2007), Minetti and Zhu (2011), and Behmina (2012) exchange rate volatility has a larger depressing effect on firms which are more financially constrained than others. Greenaway et al. (2010) suggest industry heterogeneity in response to exchange rate volatility in the UK. The results of Solakoglu (2010) suggest that larger and older firms as well as domestic market oriented firms are negatively affected from exchange rate uncertainty.

There are some other firm-level studies that focus on the effect of exchange rate movements (i.e. exchange rate appreciation and depreciation) rather than the effect of exchange rate volatility on firms' foreign sales. For instance, Berman, Martin, and Mayer (2012), and Chatterjee, Dix-Carneiro, and Vichyanond (2013) analyze the reaction of exporters to exchange rate changes and find that especially high performance and large firms react to depreciation by increasing significantly their markup and by increasing less their export volume. Li, Ma, and Xu (2015) also find for Chinese firms that the export volume responds only modestly to exchange rate changes. Using Swiss firm-level data, Lassmann (2013) discusses that export-oriented firms have larger exposure to exchange rate changes than others. However, Guillou (2008) reached the conclusion that, while changes in the exchange rate influence export entry, the effect on 
export intensity is fairly neutral for French firms.

In the Turkish context, there are only a few empirical studies on the role of exchange rate volatility on the economy. Solakoglu (2010) is the only study on the role of exchange rate volatility on the export behavior of firms in Turkey. Focusing on only 136 firms in the stock market from 2001 to 2003, it finds no significant relationship between risk and real export when aggregate risk measure is used but a significant negative impact when firms' specific risk measures are taken into account. In another paper, Demirhan (2015) analyzes the main determinants of export decisions and finds no impact of exchange rate volatility on the extensive margin. Finally, Caglayan and Demir (2014) analyze the effect of exchange rate volatility on firm productivity for the largest 1000 firms in Turkey from 1993 to 2005 and basically find that the volatility affects productivity of Turkish firms negatively and that the effect is larger for export-oriented firms than for other types of firms.

Our study contributes to the literature on the role of exchange rate volatility on international trade in some important aspects. First, we use a dataset that is fairly rich and has a long time dimension. With more than 9000 firms and more than 50,000 observations, the dataset represents the firm composition of a typical economy. Furthermore, the time dimension also allows capturing many periods of high and low volatility in the exchange rate. Second, by using only one single database, we address the differential effects of exchange rate volatility on many aspects of heterogeneity in firm characteristics, such as: (i) firm dependency on external markets, (ii) the stock market status of firms, (iii) firm size, (iv) firm maturity, and (v) sectors. Third, examining the case of Turkey is especially important because such a detailed study has not yet been done on Turkey. Turkish firms export a variety of products to many countries in different regions of the world, which further supports the view that the sample represents a typical economy. Furthermore, results are not biased to cases in which the export of a country is concentrated on a few sectors, in which most export is done to a few countries, or in which the sample does not represent the true distribution of firms in a country, such as using firms only listed on the stock market.

The rest of the paper is organized as follows. In Section 3, we introduce the model specification and the estimation of exchange rate volatility. Section 4 introduces the data in detail. We present and discuss the results in Section 5. Finally, the last section summarizes.

\section{Model}

We use the following panel regression model with either a fixed or random effect determined by Hausman test, for studying the effect of exchange rate volatility on firms' foreign sale share:

$$
\Delta \mathrm{fs}_{\mathrm{it}}=\beta_{0}+\beta_{1} \mathrm{ED}_{\mathrm{t}}+\beta_{2} \mathrm{DD}_{\mathrm{t}}+\beta_{3} \mathrm{IGI}_{\mathrm{t}}+\beta_{4} \Delta \mathrm{REER}_{\mathrm{t}-1}+\beta_{5} \mathrm{REERvol}_{\mathrm{t}-1}+\mu_{\mathrm{i}}+\varepsilon_{\mathrm{it}}
$$

where $\Delta \mathrm{fs}_{\mathrm{it}}$ represents the change in the share of foreign sales within total sales for firm i from time t-1 to time $t . \mathrm{ED}_{\mathrm{t}}$ and $\mathrm{DD}_{\mathrm{t}}$ are the growth rate of external and domestic demands, respectively. As imported intermediate goods are heavily used in the production of exporting goods in Turkey, we control the growth rate of the intermediate goods import by IGI $_{\mathrm{t}}$. $\Delta$ REER is the annual change in the real effective exchange rate. The volatility of real exchange rate is represented by REERvol, which is obtained from the GARCH(1,1) model using monthly log differences of the real effective exchange rate. Finally, we represent fixed (or random) effects by $\mu_{\mathrm{i}}$

In our dataset, we do not have exact the time of foreign sale transactions. Firms report their foreign sales at year-end, while actual transactions could happen anytime in the year from January to December. Furthermore, sometimes foreign-sale contracts with a fixed exchange rate are signed before sales. Therefore, using the year-end exchange rate and volatility of the year that the foreign sales are reported can clearly mislead the results. Therefore, we use the first lag of the exchange rate and volatility for the analysis and assume that firms take into account the exchange rate developments of previous year when deciding on their foreign sales activities in the current year.

The external demand condition is expected to have a positive impact on the foreign sale share of firms, while an increase in domestic demand is supposed to have the opposite effect. We control for intermediate goods as they constitute a significant share in the production of exporting goods. ${ }^{2}$

However, ex ante we do not know the exact effect of intermediate goods on the foreign sales of firms because there are two opposite effects. On the one hand, an increase in the growth rate of intermediate goods would imply a possible increase in the foreign sales of exporting firms. Firms can import more intermediate goods as they increase their foreign sales. Therefore, an increase in the import of intermediate goods in this case is the result of positive developments in the external demand. On the other hand, an increase in the intermediate goods could reflect simply an increase in the cost of these imported goods (regardless of external demand) which could dampen the foreign sales of firms as it would be difficult to compete in the external market.

Based on earlier firm-level studies, we expect to have a negative effect on both exchange rate and its volatility on the foreign sales of firms. An increase in the real exchange rate means appreciation of local currency, making goods to be exported more expensive and, holding all else constant, having a depressing effect on foreign sales. An increase in exchange rate volatility implies higher uncertainty in the market, which both discourages firms - especially more risk averse ones - from exporting and increases costs associated with foreign sales activities, such as hedging or market switching costs. However, the effect could vary from firm to firm, depending on such firm characteristics as size, foreign market dependency, stock market status, sector, or age.

Next, in order to analyze the differential effects of exchange rate volatility on the foreign sale share of firms, and depending on such factors as a firm's dependency on foreign market, firm size, and stock market status, we generate dummy variables $\left(D_{d, t}, D_{s m, t}, D_{l, t}, D_{m, t}\right)$ and interact them with the volatility variable in the following way:

${ }^{2}$ See Saygili, Cihan, Yalcin, and Brand (2012) for an extensive study on the role of intermediate imported goods in the manufacturing sector. 
Table 1

Descriptive statistics - full sample.

\begin{tabular}{llll}
\hline Variable & Mean & Std. Dev. & Median \\
\hline \# of Employee & 203.951 & 412.2 & 91 \\
Age & 17.774 & 11.221 & 16 \\
Foreign Sale Share & 30.753 & 32.426 & 17.108 \\
\hline
\end{tabular}

This table reports descriptive statistics of the full sample. Foreign Sale Share denotes the ratio of foreign sales to total sales.

$$
\begin{aligned}
\Delta \mathrm{fs}_{\mathrm{it}}= & \beta_{0}+\beta_{1} \mathrm{ED}_{\mathrm{t}}+\beta_{2} \mathrm{DD}_{\mathrm{t}}+\beta_{3} \mathrm{IGI}_{\mathrm{t}}+\beta_{4} \Delta \mathrm{REER}_{\mathrm{t}-1}+\beta_{5} \mathrm{REERvol}_{\mathrm{t}-1}+\left(\gamma_{1} D_{d, t}+\beta_{6} D_{d, t} \operatorname{REERvol}_{\mathrm{t}-1}\right)+\left(\gamma_{2} D_{s m, t}\right. \\
& \left.+\beta_{7} D_{s m, t} \text { REERvol }_{\mathrm{t}-1}\right)+\left(\gamma_{3} D_{l, t}+\beta_{8} D_{l, t} \mathrm{REERvol}_{\mathrm{t}-1}\right)+\left(\gamma_{4} D_{m, t}+\beta_{9} D_{m, t} \text { REERvol }_{\mathrm{t}-1}\right)+\mu_{\mathrm{i}}+\varepsilon_{\mathrm{it}}
\end{aligned}
$$

where we perform an estimation for each dummy variable (in each parenthesis) separately. The dependency dummy variable $D_{d, t}$ takes a value of 1 for firms with a share of foreign sales larger than $50 \%$ of total sales at time $t$ and zero otherwise. ${ }^{3}$ We define three dummy variables $\left(D_{s, t} D_{m, t}\right.$ and $\left.D_{m, t}\right)$ for firm size at time $\mathrm{t}$ as follows: the dummy variable for small firms $\left(D_{s, t}\right)$ takes a value of 1 if less than 50 employees; for medium firms $\left(D_{m, t}\right)$ a value of 1 if more than 49 but less than 250 employees; and for large firms $\left(D_{l, t}\right)$ a value of 1 if more than 249 employees. For all three dummy variables for firm size a zero is used otherwise. ${ }^{4}$ Finally, the dummy variable $\left(D_{s m, t}\right)$ takes the value of 1 for firms in the stock market at time $t$ and a zero otherwise.

\section{Data}

Our firm-level data comes from Company Account Statistics provided by the Central Bank of the Republic of Turkey (CBRT). This dataset contains comprehensive information at an annual frequency on financial non-financial firms in Turkey since $1989 .{ }^{5}$ The dataset contains balance sheets and income statements along with firm-specific information including employment, founding date, sector, domestic and external sales, and stock market status of firms. We exclude firms in the financial sector because its dynamics and features differ from firms in the non-financial sector. We also exclude non-exporting firms and firms with less than 10 and more than 30,000 employees. $^{6}$ Table 1 provides summary statistics for variables that are relevant to our study. The descriptive statistics show that the mean and median number of employees is about 204 and 91, respectively, and that the average age of the firms is 18 years. Foreign sales constitutes about $31 \%$ of total sales for an average exporting firm while the share is about $17 \%$ for the median firm.

In Table 2 we display the descriptive statistics for sample groups. According to Panel A, in which firms are classified according to size, large firms are, on average, older and have a higher foreign share than other firms. Similarly, medium-size firms are older and have a higher share of foreign sales than small-size firms. In Panel B, we classify firms according to their dependency on foreign markets. The average share of foreign sales in the more dependent group is $81 \%$ of total sales, while it is $15 \%$ for the less dependent group. Less dependent firms are, on average, larger and older than more dependent firms. In the last panel, we compare firms according to their stock market status. The table shows that firms traded in the stock market are larger and older than the firms that are not traded in the stock market. However, the former group of firms has a smaller foreign sale share than the latter group.

We obtain macroeconomic data from both the CBRT and the Turkish Statistical Institute (Turkstat). In order to have a proper external demand, we take the average of the real growth rate of GDP for the top twenty exporting countries of Turkey weighted by their export share within the total export of Turkey for each year. ${ }^{7}$ For domestic demand, we do not use the growth rate of Turkish GDP because this variable has a high correlation with the growth rate of the imported intermediate goods. Instead and as a better measure for domestic demand, we proxy the domestic demand by the real growth rate of private and public sectors consumption. As stated above, we use the growth rate of imported intermediate goods as these goods to a great degree are used for the production of exporting goods. Finally, we obtain the real effective exchange rate provided by the CBRT for both the estimation of the exchange rate volatility and as a variable in the analysis. It is computed as weighted geometric average of the prices in Turkey relative to the prices of its main trading partners. We use annual average of monthly real exchange rate.

Fig. 1 displays the evolution of macroeconomic variables for the time period of 1989-2013. We observe that external demand declined during the recent financial crisis while the domestic variables perform very poorly during the domestic crisis of 1994 and 2001 and during the recent global financial crisis, which began in 2008. At the same time, volatility increased during 1994 and 2001 crisis.

\footnotetext{
${ }^{3}$ An alternative way is to label firms with more than the median foreign sale share of the sample as more dependent and otherwise less dependent. However, the median foreign sale share is much lower (18\%), and it would be difficult to interpret firms which are barely above the median (say at $20 \%$ ) as foreign market dependent firms.

4 This classification is defined by the European Commission and widely accepted for the Euro area.

5 The Company Account Statistics is the most comprehensive firm level data that contains detailed information about firms in Turkey. It includes firms listed in Borsa Istanbul (Istanbul Stock Market), the Top 500 Industrial Enterprises of Istanbul Chamber of Industry in addition to firms not appeared in these lists. For instance, the 2013 survey covers more than 10000 firms with more than 2 million employees $(8.18 \%$ of Turkish employees).

6 We exclude firms with more than 30000 employees to eliminate outliers.

7 These countries are Germany, Iraq, England, Italy, France, United States, Russia, Spain, United Arab Emirates, Iran, Holland, Egypt, Switzerland, Saudi Arabia, Romania, Israel, Belgium, Azerbaijan, China, and Poland. We exclude Azerbaijan before 1992 and Iraq between 1997 and 2002 since we do not have data for these two countries in these periods. The total export to these twenty countries constitutes more than $70 \%$ of Turkish export.
} 
Table 2

Descriptive statistics - sub-sample.

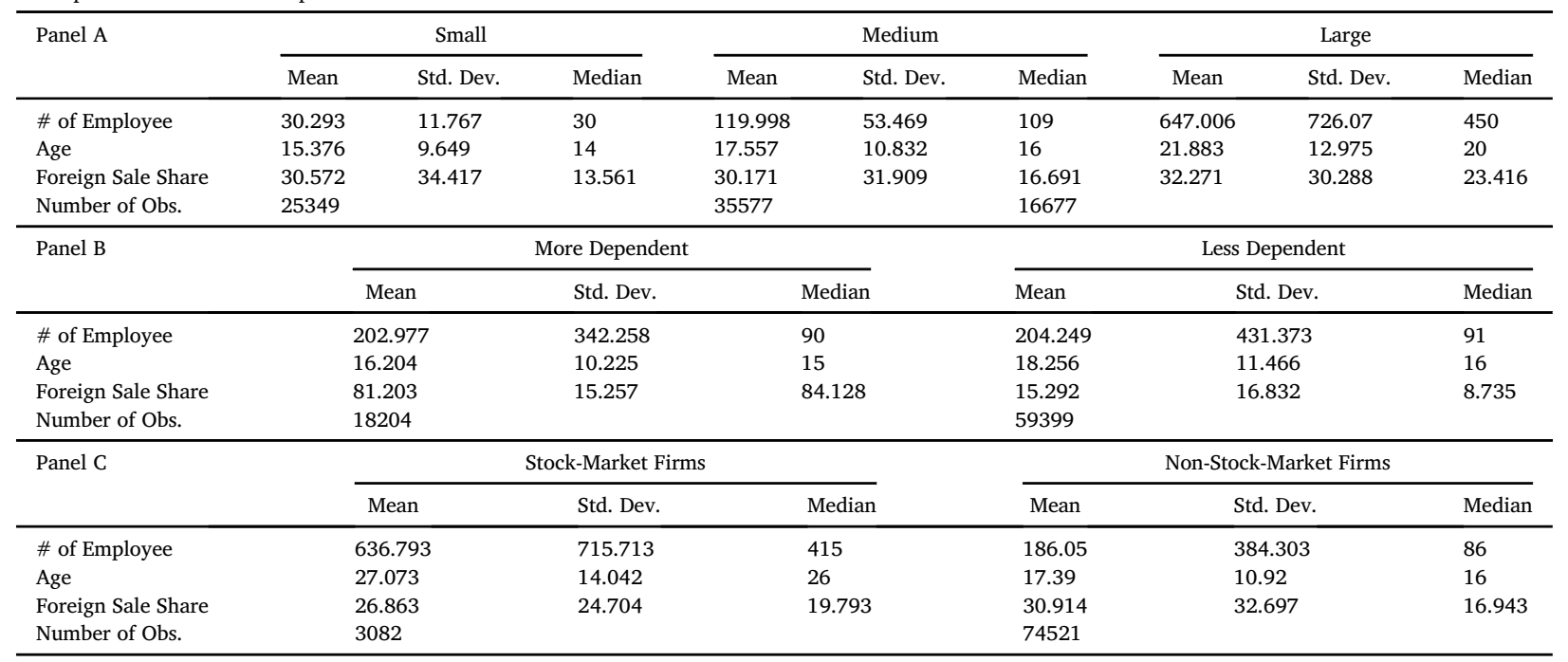

This table displays descriptive statistics for three sub-samples. In Panel A, firms are classified according to their number of employees as small (greater than 10 and less than 50), medium (greater than 49 and less than 250), and large (greater than 249). In Panel B, firms are classified regarding their foreign market dependency. Firms with more than $50 \%$ of their sales in foreign markets are labeled more dependent firms, the rest as less dependent firms. Last, in Panel C, firms are classified according to their stock market status. Firms that are listed in the stock market are labeled as Stock Market Firms, and the rest are labeled as Non-Stock Market Firms. Foreign Sale Share denotes the ratio of foreign sales to total sales. Mean comparison tests suggests that the means across samples are not statistically significant.

\section{Results}

\subsection{Full-sample results}

We first analyze the effect of exchange rate volatility on firms' foreign sale shares using the full sample and present the results in Table 3. In the first column, we present results of the baseline model in Eqn (1) without taking into account any firm classifications. In columns 2 to 4, we include the interaction of the volatility variable with dummy variables for dependency, firm size, and stock market status separately.

The estimates of the macro variables do not change dramatically across model specifications. The demand variables have expected signs. While improvements in external demand lead to significant increase in the foreign sale shares of firms, increases in domestic demand lead firms to shift sales partly from the external market to the domestic market. The growth rate of imported intermediate goods has a negative impact on the foreign sale shares of firms, indicating that the growth rate of intermediate goods mainly reflects increases in the prices of these goods. As the production cost increases for domestic firms, they lose external market power. We further find that the appreciation of domestic currency has a depressing effect on firms' foreign sale shares across all specifications simply because domestic products become more expensive in the external market as domestic currency appreciates against the US dollar. The effect is robust and does not change across model specifications. More precisely and quantitatively, a one percentage point appreciation of the domestic currency (i.e. increase in the REER) reduces foreign sale share of an average firm by $5.9 \%$.

In the full sample baseline model, the effect of exchange rate volatility has a significant depressing effect on the foreign sale shares of firms. An increase by one standard deviation (0.879) in the REER volatility depresses foreign sale shares of an average firm by $13.3 \%$ $(0.879 \times 0.151)$. This negative impact of exchange rate volatility is consistent with the findings of some earlier studies such as Cheung and Sengupta (2013), Hericourt and Nedoncelle (2015), Dekle and Ryoo (2007), Hericourt and Poncet (2013), and Solakoglu (2010). The negative effect of volatility supports the argument that high level of volatility generates high level of uncertainty and increases the costs of foreign sales. However, in column 2 where we control for firm dependency, the results indicate that while less dependent firms are negatively affected from exchange rate volatility, the effect on more dependent firms is less negative, and indeed the total effect on these firms $\left(\beta_{5}+\beta_{6}\right)$ is insignificant. As the more dependent firms have over $50 \%$ of their total sales in foreign markets, they are more focused on external markets and are expected to have the incentives and means to reduce the possible negative effects of exchange rate volatility on their foreign sales, via hedging, invoicing strategies, or redirecting their foreign sales to other countries and regions.

In column 3 where we control for the stock market status of firms, the results suggest that the foreign sale shares of firms not listed in the stock market is significantly negatively affected from exchange rate volatility. The interaction term between exchange rate volatility and the stock market dummy variable $\left(\beta_{7}\right)$ and the total effect for the firms in the stock market $\left(\beta_{5}+\beta_{7}\right)$ is insignificant which implies that foreign sale shares of firms listed in the stock market is not exposed to exchange rate volatility. Similar to more dependent firms, they are more likely to have resources, incentives, and easy access to the means necessary to reduce risks generated from exchange rate volatility. The characteristic differences between firms listed and not listed in the stock market and the differential impact of the volatility on the foreign sale shares of these two types of firms indicate that the results of studies which do not differentiate between 

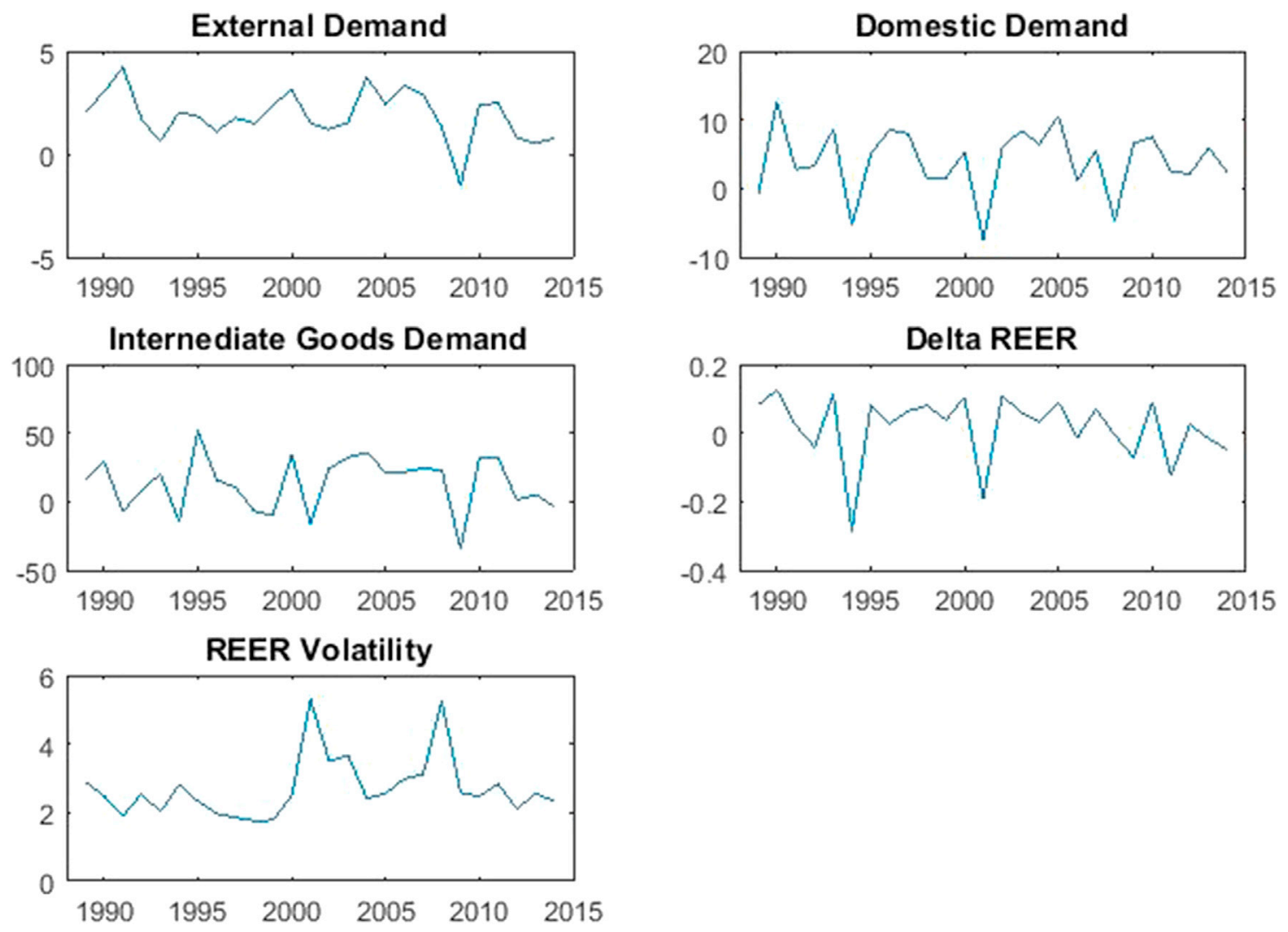

Fig. 1. Macroeconomic variables over time.

Table 3

Baseline results.

\begin{tabular}{|c|c|c|c|c|}
\hline Variables & Basic & Dep & Stock & Size \\
\hline External Demand $\left(\beta_{1}\right)$ & $0.338^{* * *}(0.071)$ & $0.341 * * *(0.071)$ & $0.338^{* * *}(0.071)$ & $0.298 * * *(0.079)$ \\
\hline Domestic Demand $\left(\beta_{2}\right)$ & $-0.151^{* * *}(0.016)$ & $-0.151^{* * *}(0.016)$ & $-0.151^{* * *}(0.016)$ & $-0.145^{* * *}(0.017)$ \\
\hline Int. Goods Imp. $\left(\beta_{3}\right)$ & $-0.037 * * *(0.004)$ & $-0.037 * * *(0.004)$ & $-0.037 * * *(0.004)$ & $-0.038 * * *(0.005)$ \\
\hline Delta ER. $\left(\beta_{4}\right)$ & $-0.059 * * *(0.009)$ & $-0.059 * * *(0.009)$ & $-0.059 * * *(0.009)$ & $-0.060 * * *(0.010)$ \\
\hline REER Vol. $\left(\beta_{5}\right)$ & $-0.151 * *(0.067)$ & $-0.175^{* *}(0.074)$ & $-0.144 * *(0.068)$ & $-0.059(0.127)$ \\
\hline DD*REER Vol. $\left(\beta_{6}\right)$ & & $0.108(0.132)$ & & \\
\hline SD*REER Vol. $\left(\beta_{7}\right)$ & & & $-0.143(0.273)$ & \\
\hline MD*REER Vol. $\left(\beta_{8}\right)$ & & & & $-0.256 *(0.150)$ \\
\hline LD*REER Vol. $\left(\beta_{9}\right)$ & & & & $-0.231(0.175)$ \\
\hline$\beta_{5}+\beta_{6}$ & & $-0.0674(0.119)$ & & \\
\hline$\beta_{5}+\beta_{7}$ & & & $-0.287(0.268)$ & \\
\hline$\beta_{5}+\beta_{8}$ & & & & $-0.315^{* * *}(0.101)$ \\
\hline$\beta_{5}+\beta_{9}$ & & & & $-0.290 * *(0.134)$ \\
\hline Observations & 56,714 & 56,714 & 56,714 & 56,714 \\
\hline Number of firms & 10,092 & 10,092 & 10,092 & 10,092 \\
\hline Hausman & 8.247 & 10.48 & 8.227 & 24.68 \\
\hline haus_p & 0.143 & 0.163 & 0.222 & 0.00335 \\
\hline
\end{tabular}

This table displays the estimation results for the full-sample. In the first column no firm classification is included while in the subsequent columns, foreign market dependency (Dep), stock market status (Stock), and firm-size classification (Size) are included, respectively. DD*REER Vol, SD*REER Vol., MD*REER Vol., and LD*REER Vol. stand for the interaction of real effective exchange rate and dummy variables for dependency, stock market status, medium-size firms, and large-size firms, respectively. All firms are classified according to the number of employees as small (greater than 10 and less than 50), medium (greater than 49 and less than 250 ), and large (greater than 249); according to foreign market dependency as more dependent (foreign sales $<$ Roman $>=</$ Roman $>50 \%$ of total sales) and less dependent (foreign sales $>50 \%$ of total sales); and according to stock market status as listed or not listed in the stock market. Large p-value in Hausman test (haus_p) favors random effect model while usual lower levels favors fixed-effect models. The coefficients of dummy variables are omitted. Standard errors are in parentheses. ${ }^{* * *} \mathrm{p}<0.01,{ }^{* * \mathrm{p}}<0.05$, $* \mathrm{p}<0.1$. 
these two types of firms should not be generalized to the all firms in a country's economy.

Next, we control for firms' size by including dummy variables for medium- and large-sized firms and by looking at the firms' interaction with volatility. The results reported in the fourth column of Table 3 indicate that, for small-sized firms, exchange rate volatility has no exposure on foreign sale shares but that this volatility has a more negative effect on medium-sized firms. The total effects on the medium and large firms $\left(\beta_{5}+\beta_{8}\right.$ and $\left.\beta_{5}+\beta_{9}\right)$ are significantly negative. We believe that medium-sized firms are exposed to exchange rate volatility as they are more likely to increase their foreign sales given small export incentives. In a recent paper using Colombian data, Kandilov and Leblebicioglu (2014) also find that the volatility impact is larger for firms in the second quartile of the size distribution.

The apparent success of small firms at avoiding the adverse effect from exchange rate volatility could be attributed to their flexibility in switching sales to a third country as the volume of their foreign sales are usually lower than that of medium and larger firms. Further, it is easier for small firms to target small, new, and more profitable markets than it is for medium and large firms. In addition to having fewer employees, small firms are younger than the other firms.

\subsection{Split-sample results}

In this section, we split the full sample into sub groups according to three measures: firm dependency on foreign sales, stock market status, and firm size. Our aim is to elaborate further the effect of exchange rate volatility on foreign sale shares of firms based on these subsets and to examine the robustness of the full sample estimates. Furthermore, while the full sample estimates impose the same effect for each macro variable (i.e., external and domestic demand, intermediate goods import, and exchange rate), it is possible that the effects of these macro variables could vary considerably for sub-samples.

We first split our sample according to foreign sale shares of firms, classifying firms as more dependent if foreign sales constitute more than $50 \%$ of its total sales and less dependent otherwise. In Table 4 results are shown, with more dependent firms in the first three columns and the less dependent firms in the last three columns. The results indicate that positive developments in external demand contribute to foreign sale shares of firms, with the effect being larger for less dependent ones. Positive developments in domestic demand reduces foreign sale shares of firms, but the reduction is larger for less dependent firms than for the more dependent ones. Similar to the baseline case, increasing intermediate goods import and the real exchange rate appreciations have a dampening impact on foreign sale shares for both dependent and less dependent firms.

The results, corroborating the full model result, show that exchange rate volatility has no depressing impact on foreign sale shares of more dependent firms in general, as $\beta_{5}$ in the first column of Table 4 is not significant. However, the results also show that more dependent firms listed in the stock market are more negatively affected from exchange rate volatility than more dependent firms not listed in the stock market, as $\beta_{7}$ in the second columns is significant at the $10 \%$ level. The effect of considering both exchange rate volatility and stock market status $\left(\beta_{5}+\beta_{7}\right)$ for more dependent stock market firms is also significantly negative. The third column in the table indicates that medium-size more dependent firms experience significant negative exposure of exchange rate volatility on their foreign sale shares, as both $\beta_{8}$ and $\beta_{5}+\beta_{8}$ are negative at the $1 \%$ level. However, there is no effect of volatility for more dependent smalland large-sized firms' foreign sale shares.

In the last three columns of Table 4, the estimation results for less dependent firms reveal that exchange rate volatility has a large

Table 4

Split-sample: Foreign market dependency.

\begin{tabular}{|c|c|c|c|c|c|c|}
\hline \multirow[t]{2}{*}{ Variables } & \multicolumn{3}{|l|}{ More Dependent } & \multicolumn{3}{|l|}{ More Dependent } \\
\hline & Basic & Stock & Size & Basic & Stock & Size \\
\hline External Demand $\left(\beta_{1}\right)$ & $0.253^{* *}(0.103)$ & $0.252 * *(0.103)$ & $0.252 * *(0.103)$ & $0.343^{* * *}(0.088)$ & $0.343 * * *(0.088)$ & $0.341 * * *(0.088)$ \\
\hline Domestic Demand $\left(\beta_{2}\right)$ & $-0.098^{* * *}(0.024)$ & $-0.099 * * *(0.024)$ & $-0.099 * * *(0.024)$ & $-0.168 * * *(0.019)$ & $-0.168^{* * *}(0.019)$ & $-0.168^{* * *}(0.019)$ \\
\hline Int. Goods Imp. $\left(\beta_{3}\right)$ & $-0.030 * * *(0.006)$ & $-0.030 * * *(0.006)$ & $-0.030 * * *(0.006)$ & $-0.040 * * *(0.005)$ & $-0.040 * * *(0.005)$ & $-0.040 * * *(0.005)$ \\
\hline Delta ER. $\left(\beta_{4}\right)$ & $-0.045^{* * *}(0.013)$ & $-0.045^{* * *}(0.013)$ & $-0.045^{* * *}(0.013)$ & $-0.065^{* * *}(0.011)$ & $-0.065^{* * *}(0.011)$ & $-0.065^{* * *}(0.011)$ \\
\hline REER Vol. $\left(\beta_{5}\right)$ & $-0.120(0.098)$ & $-0.093(0.099)$ & $0.240(0.161)$ & $-0.178 * *(0.084)$ & $-0.182 * *(0.086)$ & $-0.086(0.139)$ \\
\hline SD*REER Vol. $\left(\beta_{7}\right)$ & & $-0.765 *(0.456)$ & & & $0.082(0.321)$ & \\
\hline MD*REER Vol. $\left(\beta_{8}\right)$ & & & $-0.611^{* * *}(0.196)$ & & & $-0.119(0.166)$ \\
\hline LD*REER Vol. $\left(\beta_{9}\right)$ & & & $-0.333(0.225)$ & & & $-0.167(0.198)$ \\
\hline$\beta_{5}+\beta_{7}$ & & $-0.858 *(0.450)$ & & & $-0.101(0.315)$ & \\
\hline$\beta_{5}+\beta_{8}$ & & & $-0.372 * * *(0.134)$ & & & $-0.205 *(0.112)$ \\
\hline$\beta_{5}+\beta_{9}$ & & & $-0.0928(0.174)$ & & & $-0.253(0.155)$ \\
\hline Observations & 13,638 & 13,638 & 13,638 & 43,076 & 43,076 & 43,076 \\
\hline Number of firms & 2920 & 2920 & 2920 & 8689 & 8689 & 8689 \\
\hline Hausman & 8.032 & 9.878 & 14.67 & 3.402 & 3.675 & 12.68 \\
\hline haus_p & 0.155 & 0.130 & 0.100 & 0.638 & 0.721 & 0.178 \\
\hline
\end{tabular}

This table displays the estimation results for the split-sample. In the first and the fourth columns no firm classification is included while in the subsequent columns stock market status (Stock) and firm size classification (Size) are included, respectively. SD*REER Vol., MD*REER Vol., and LD*REER Vol. stand for the interaction of real effective exchange rate and dummy variables for the stock market status, medium-size firms, and large-size firms, respectively. All firms are classified according to the number of employees as small (greater than 10 and less than 50), medium (greater than 49 and less than 250), and large (greater than 249); according to foreign market dependency as more dependent (foreign sales $<$ Roman $>=</$ Roman $>50 \%$ of total sales) and less dependent (foreign sales $>50 \%$ of total sales); and according to stock market status as listed or not listed in the stock market. Large p-value in Hausman test (haus_p) favors random effect model while usual lower levels favors fixed-effect models. The coefficients of dummy variables are omitted. Standard errors are in parentheses. ${ }^{* * *} \mathrm{p}<0.01,{ }^{* *} \mathrm{p}<0.05,{ }^{*} \mathrm{p}<0.1$. 
depressing impact on the foreign sale shares of less dependent firms. However, less dependent firms listed in the stock market do not observe any significant effect, as columns 5 shows that $\beta_{7}$ and $\beta_{5}+\beta_{7}$ are not significant, while the effect for less dependent firms not listed in the stock market is observable. In the last column of the table, where we classify less dependent firms according to their sizes, the results (i.e., $\beta_{8}$ and $\beta_{9}$ ) suggest that the effect of volatility is not significant for small, medium, or large firms but that the total effect of volatility is significant at the $10 \%$ level for medium firms $\left(\beta_{5}+\beta_{8}\right)$ and only barely insignificant for large firms $\left.\beta_{5}+\beta_{9}\right)$.

More dependent firms are expected to have sales activity in multiple foreign markets compared to less dependent firms. In addition to being familiar with the instruments to reduce the uncertainty generated from exchange rate volatility, having operations in multiple foreign markets brings about a kind of natural hedging mechanism against exchange rate volatility. As Hericourt and Nedoncelle (2015) find, more destination-diversified firms are able to better cope with exchange rate volatility risk. In order to elaborate further upon the differential effects of exchange rate volatility on foreign sale shares, we next split our sample into firms traded and non-traded in the stock market and with results are in Table 5. The first three columns display the results for firms listed in the stock market and the latter three columns display the results for not-listed firms. External demand has a positive impact on foreign sale shares of firms not listed in the stock market but, surprisingly, has no significant impact on foreign sale shares of firms listed in the stock market. The effects of other macro variables corroborate the results in the baseline case. Comparatively, domestic demand and REER have larger depressing effects on foreign sale shares of firms listed in the stock market than those not listed.

The results show that exchange rate volatility has no significant effect on the foreign sale shares of firm listed in the stock market; further, the effect does not change according to firm size or firm foreign market dependency. On the other hand, not being listed in the stock market has a large depressing impact on the foreign sale shares ( $\beta_{5}$ in column 4$)$. However, the effect varies considerably according to firm classifications. While more dependent firms not listed in the stock market experience no exposure of exchange rate volatility, as $\beta_{6}$ and $\beta_{5}+\beta_{6}$ are not significant, the effect is significant for less dependent firms not listed in the stock market. Finally, the last column reveals that while medium and large firms not listed in the stock market have significant exposure to exchange rate volatility (at the $1 \%$ and $10 \%$ significance level, respectively), small firms do not observe any significant effect.

The differential impacts of real exchange rate volatility between firms listed and not-listed in the stock market could be attributed to the characteristic differences between these two types of firms. For instance, stock market firms are usually more professionally managed in terms of both short-run and long-run objectives than non-stock market firms. They are more transparent and usually don't take uncalculated risk. Furthermore, these firms are obliged to report their balance sheets and financials regularly to the public.

Next, we classify the full sample into three categories according to the number of employees as small (greater than 10 and less than 50), medium (greater than 49 and less than 250), and large (greater than 249). Table 6 displays the results for these three classes, where the first three columns represent the results for small firms, the next three columns for medium firms, and the last three columns for large firms. The split-sample results indicate that as firms become larger, the impact on external demand magnifies. While external demand has no significant impact on foreign sale shares of small firms, the effect is the largest for large firms. Domestic demand has a less depressing impact on small firms, but the same-magnitude impact on both medium and large firms. The effect of intermediate goods import and exchange rate are similar across firm-size classifications.

Exchange rate volatility has no depressing effect on small firms (columns 1 and 2 of Table 6) and large firms (column 5 and 6 of Table 6), regardless of foreign market dependency or stock market status, as the coefficients for volatility $\left(\beta_{5}\right)$, interaction $\left(\beta_{6}\right.$ and $\left.\beta_{7}\right)$, and total effect $\left(\beta_{5}+\beta_{6}\right.$ and $\left.\beta_{5}+\beta_{7}\right)$ are not different from zero. The estimation results for medium-size firms indicate that exchange rate

Table 5

Split-sample: Stock market status.

\begin{tabular}{|c|c|c|c|c|c|c|}
\hline \multirow[t]{2}{*}{ Variables } & \multicolumn{3}{|l|}{ Stock Market Firms } & \multicolumn{3}{|c|}{ Non-Stock Market Firms } \\
\hline & Basic & Dep & Size & Basic & Dep & Size \\
\hline External Demand $\left(\beta_{1}\right)$ & $0.160(0.228)$ & $0.165(0.228)$ & $0.154(0.228)$ & $0.343^{* * *}(0.073)$ & $0.346^{* * *}(0.073)$ & $0.303^{* * *}(0.083)$ \\
\hline Domestic Demand $\left(\beta_{2}\right)$ & $-0.240 * * *(0.058)$ & $-0.242^{* * *(0.058)}$ & $-0.242^{* * *(0.058)}$ & $-0.147 * * *(0.017)$ & $-0.147 * * *(0.017)$ & $-0.140 * * *(0.018)$ \\
\hline Int. Goods Imp. $\left(\beta_{3}\right)$ & $-0.030 * *(0.013)$ & $-0.030 * *(0.013)$ & $-0.029 * *(0.013)$ & $-0.037 * * *(0.004)$ & $-0.037 * * *(0.004)$ & $-0.038^{* * *}(0.005)$ \\
\hline Delta ER. $\left(\beta_{4}\right)$ & $-0.094^{* * *}(0.033)$ & $-0.093^{* * *}(0.033)$ & $-0.095^{* * *(0.033)}$ & $-0.058 * * *(0.009)$ & $-0.057 * * *(0.009)$ & $-0.058 * * *(0.010)$ \\
\hline REER Vol. $\left(\beta_{5}\right)$ & $-0.290(0.224)$ & $-0.169(0.244)$ & $0.758(0.930)$ & $-0.142 * *(0.069)$ & $-0.175^{* *}(0.077)$ & $-0.065(0.129)$ \\
\hline DD*REER Vol. $\left(\beta_{6}\right)$ & & $-0.583(0.499)$ & & & $0.139(0.136)$ & \\
\hline MD*REER Vol. $\left(\beta_{8}\right)$ & & & $-0.985(0.996)$ & & & $-0.249(0.153)$ \\
\hline LD*REER Vol. $\left(\beta_{9}\right)$ & & & $-1.103(0.951)$ & & & $-0.208(0.185)$ \\
\hline$\beta_{5}+\beta_{6}$ & & $-0.752(0.461)$ & & & $-0.0364(0.123)$ & \\
\hline$\beta_{5}+\beta_{8}$ & & & $-0.227(0.398)$ & & & $-0.314 * * *(0.104)$ \\
\hline$\beta_{5}+\beta_{9}$ & & & $-0.345(0.259)$ & & & $-0.273 *(0.147)$ \\
\hline Observations & 2573 & 2573 & 2573 & 54,141 & 54,141 & 54,141 \\
\hline Number of firms & 223 & 223 & 223 & 9869 & 9869 & 9869 \\
\hline Hausman & 2.691 & 4.426 & 6.037 & 8.057 & 9.973 & 25.59 \\
\hline haus_p & 0.748 & 0.730 & 0.736 & 0.153 & 0.190 & 0.00238 \\
\hline
\end{tabular}

This table displays the estimation results for the split-sample. In the first and the fourth columns no firm classification is included while in the subsequent columns, foreign market dependency (Dep), and firm size classification (Size) are included, respectively. DD*REER Vol, MD*REER Vol., and LD*REER Vol. stand for the interaction of real effective exchange rate and dummy variables for dependency, medium-size firms, and large-size firms, respectively. All firms are classified according to the number of employees as small (greater than 10 and less than 50), medium (greater than 49 and less than 250), and large (greater than 249); according to foreign market dependency as more dependent (foreign sales $<$ Roman $>=</$ Roman $>50 \%$ of total sales) and less dependent (foreign sales $>50 \%$ of total sales); and according to stock market status as listed or not listed in the stock market. Large p-value in Hausman test (haus_p) favors random effect model while usual lower levels favors fixed-effect models. The coefficients of dummy variables are omitted. Standard errors are in parentheses. ${ }^{* *} \mathrm{p}<0.01,{ }^{* *} \mathrm{p}<0.05,{ }^{*} \mathrm{p}<0.1$. 
Table 6

Split-sample: Firm size.

\begin{tabular}{|c|c|c|c|c|c|c|c|c|c|}
\hline \multirow{2}{*}{ Variables } & \multicolumn{3}{|l|}{ Small } & \multicolumn{3}{|l|}{ Medium } & \multicolumn{3}{|l|}{ Large } \\
\hline & Basic & Dep. & Stock & Basic & Dep. & Stock & Basic & Dep. & Stock \\
\hline External Demand $\left(\beta_{1}\right)$ & $0.107(0.182)$ & $0.111(0.182)$ & $0.107(0.182)$ & $0.320 * * *(0.105)$ & $0.320 * * *(0.105)$ & $0.320 * * *(0.105)$ & $0.519 * * *(0.133)$ & $0.518 * * *(0.133)$ & $0.519 * * *(0.133)$ \\
\hline Domestic Demand $\left(\beta_{2}\right)$ & $-0.078 * *(0.038)$ & $-0.078 * *(0.038)$ & $-0.078^{* *}(0.038)$ & $-0.158^{* * *}(0.024)$ & $-0.159^{* * *}(0.024)$ & $-0.158^{* * *}(0.024)$ & $-0.160^{* * * *}(0.030)$ & $-0.160^{* * * *}(0.030)$ & $-0.160^{* * *}(0.030)$ \\
\hline Int. Goods Imp. $\left(\beta_{3}\right)$ & $-0.025^{* *}(0.010)$ & $-0.025 * *(0.010)$ & $-0.025^{* *}(0.010)$ & $-0.040 * * *(0.006)$ & $-0.040^{* * *}(0.006)$ & $-0.040 * * *(0.006)$ & $-0.049^{* * *}(0.008)$ & $-0.049 * * *(0.008)$ & $-0.049 * * *(0.008)$ \\
\hline Delta ER. $\left(\beta_{4}\right)$ & $-0.069^{* * *}(0.022)$ & $-0.069 * * *(0.022)$ & $-0.069^{* * * *}(0.022)$ & $-0.063^{* * *}(0.013)$ & $-0.063^{* * *}(0.013)$ & $-0.063 * * *(0.013)$ & $-0.061^{* * *}(0.017)$ & $-0.062 * * *(0.017)$ & $-0.061 * * *(0.017)$ \\
\hline REER Vol. $\left(\beta_{5}\right)$ & $-0.158(0.172)$ & $-0.275(0.191)$ & $-0.160(0.172)$ & $-0.266^{* * *}(0.098)$ & $-0.233^{* *}(0.109)$ & $-0.266 * * *(0.099)$ & $-0.142(0.132)$ & $-0.173(0.149)$ & $-0.120(0.141)$ \\
\hline DD*REER Vol. $\left(\beta_{6}\right)$ & & $0.463(0.317)$ & & & $-0.131(0.195)$ & & & $0.175(0.252)$ & \\
\hline SD*REER Vol. $\left(\beta_{7}\right)$ & & & $0.453(1.920)$ & & & $0.012(0.532)$ & & & $-0.139(0.313)$ \\
\hline$\beta_{5}+\beta_{6}$ & & $0.188(0.291)$ & & & $-0.363^{* *}(0.178)$ & & & $0.001(0.225)$ & \\
\hline$\beta_{5}+\beta_{7}$ & & & $0.293(1.918)$ & & & $-0.254(0.528)$ & & & $-0.259(0.295)$ \\
\hline Observations & 16,534 & 16,534 & 16,534 & 26,585 & 26,585 & 26,585 & 13,595 & 13,595 & 13,595 \\
\hline Number of firms & 4986 & 4986 & 4986 & 6344 & 6344 & 6344 & 2373 & 2373 & 2373 \\
\hline Hausman & 18.18 & 20.71 & 18.22 & 4.106 & 7.605 & 4.230 & 11.77 & 15.08 & 12.06 \\
\hline haus_p & 0.00273 & 0.00422 & 0.00569 & 0.534 & 0.369 & 0.646 & 0.0381 & 0.0350 & 0.0607 \\
\hline
\end{tabular}

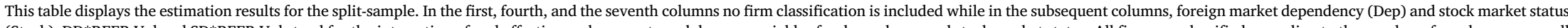

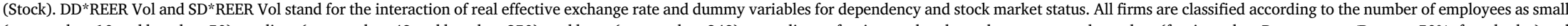

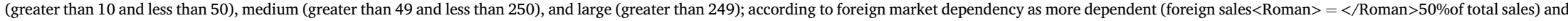

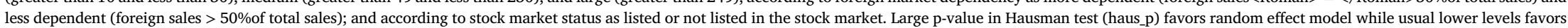
fixed-effect models. The coefficients of dummy variables are omitted. Standard errors in are parentheses. ${ }^{* * *} \mathrm{p}<0.01,{ }^{* *} \mathrm{p}<0.05,{ }^{*} \mathrm{p}<0.1$. 
volatility has a significant depressing impact on the foreign sale shares at the $1 \%$ level (column 4 ).

Large firms might not be affected from exchange rate volatility as they would likely have sales activity in foreign markets. They are expected to protect themselves from exchange rate volatility through easy access to credit markets and mechanisms to alleviate the negative effects of the volatility. Small firms also seems to be more flexible to reduce the negative effect of exchange rate volatility. They are expected to switch their sales to a third market more easily than other firms. The larger negative effect of the volatility on mediumsized firms could be due to many factors including their relative inflexibility, difficult and more costly to access hedging instruments, prompt response to small export incentives.

However, the effect differs somewhat when breaking down medium-size firms based on foreign market dependency and stock market participation. According to these results, exchange rate volatility has negative impact on foreign sale shares of medium firms regardless of their foreign market dependency. The magnitude of the effect for medium firms is larger for more dependent firms. The sixth column of the table indicates that while medium-sized firms listed in the stock market do not observe any impact based on exchange rate volatility on foreign sale shares, as both $\beta_{7}$ and $\beta_{5}+\beta_{7}$ are not significant, the effect is significant for medium-size firms not listed in the stock market.

\subsection{Extensions}

In this section, we investigate the impact of exchange rate volatility on foreign sale shares of firms, stratifying based on (i) manufacturing and service sector firms and (ii) mature and non-mature firms.

We split our firms by manufacturing and service sectors so as to examine if exchange rate volatility has a differential effect on foreign sale shares based on these two categories. Regarding macro variables, the results in Table 7 show that external demand has a larger positive impact on foreign sale shares for manufacturing firms than for service sector firms. Another noticeable difference comes from the intermediate goods import. The effect is negative for manufacturing firms but insignificant for service sector firms since they do not use these intermediate goods for the production of final goods. The effects of domestic demand and exchange rate are similar for both sectors.

The results regarding exchange rate volatility indicate that this factor has no depressing effect on the foreign sale shares of service sector firms in general or any type of firm in this category, as all coefficients related to the volatility are not different from zero. However, for the manufacturing sector, exchange rate volatility has a large negative impact on the foreign sale shares of manufacturing firms. The effect is not significant for manufacturing firms that are foreign market dependent, that are listed in the stock market, and that are small in size. However, the foreign sale shares of manufacturing firms that are less dependent on foreign markets, not listed in the stock market, or medium- or large-sized experience significant exposure based on exchange rate volatility.

Finally, we categorize firms according to their age, with those above medium age of 16 years being mature and those below as nonmature firms. We expected mature firms to experience lower exposure of exchange rate volatility. The results of this exercise reported in Table 8 indicate that the effects of macro variables are very similar for both mature and non-mature firms.

Exchange rate volatility has a negative impact on both mature and non-mature firms on average ( $\beta_{5}$ in Columns 1 and Column 5 ). However, the magnitude of the effect is larger for non-mature firms. When we introduce firm dependency on the foreign market, the effect disappears for both more and less dependent mature firms while less dependent non-mature firms still observe significant negative exposure of exchange rate volatility on their foreign sale shares when compared to more dependent mature firms. Similarly, when introducing the stock market status of firms, only non-mature firms not listed in the stock market are exposed to a negative impact of exchange rate volatility. Interestingly while exchange rate volatility has depressing impact on small and medium size non-mature firms, the effect is significant for medium and large mature firms. One further important observation is that among the significant effects the magnitude of the effects are larger for non-mature firms than that for the mature firms.

We check the robustness of the main results by modifying and re-estimating the baseline model with industry fixed effects. The results reported on Table 9 indicate that the baseline results reported on Table 3 are robust to industry fixed effect. The magnitude of the coefficients of the exchange rate volatility are very similar and their significance levels don't change when we control for industry specific characteristics.

\section{Conclusion}

In this paper, we investigate the impact of exchange rate volatility on the foreign sale shares utilizing firm-level Turkish data. The rich dataset allows us to take into account different heterogeneity across firms. We find that although an increase in exchange rate volatility depresses foreign sale shares of firms in general, the effect differs heavily when depending on such factors as foreign market dependency, stock market status, firm size, firm age, and the sector. Overall, the volatility has a significant depressing impact on the foreign sale shares of firms that are less dependent on the foreign market, not listed in the stock market, or medium- or large-sized. In other words, foreign market dependent firms, firms listed in the stock market and small firms do not observe the negative impact of exchange rate volatility. Furthermore, young firm or firms in the manufacturing sector are exposed to the export-deterring effects of exchange rate volatility.

Some policy implications can be drawn from this study. The results indicate that for a small open economy, like Turkey, an increase in exchange rate volatility has a depressing influence on foreign sales activity of firms. Therefore, exchange rate stability and reducing risks generated by exchange rate uncertainty can potentially increase export. However, as the results further suggest that the effect of volatility is not the same across firms with different characteristics. Not all firms are equally exposed to exchange rate volatility. While the volatility has a depressing impact on the foreign sales activity of some firms, other firms are immune to such volatility. Therefore, 
Table 7

Split-sample: Sectors.

\begin{tabular}{|c|c|c|c|c|c|c|c|c|}
\hline \multirow[t]{2}{*}{ Variables } & \multicolumn{4}{|l|}{ Manufacturing } & \multicolumn{4}{|l|}{ Service } \\
\hline & Basic & Dep. & Stock & Size & Basic & Dep. & Stock & Size \\
\hline External Demand $\left(\beta_{1}\right)$ & $0.359 * * *(0.080)$ & $0.346^{* * * *}(0.088)$ & $0.358^{* * *}(0.080)$ & $0.341^{* * *}(0.088)$ & $0.255 *(0.144)$ & $0.258 *(0.144)$ & $0.256 *(0.144)$ & $0.251 *(0.144)$ \\
\hline Domestic Demand $\left(\beta_{2}\right)$ & $-0.154^{* * *}(0.019)$ & $-0.146^{* * *}(0.020)$ & $-0.154^{* * *}(0.019)$ & $-0.145^{* * *}(0.020)$ & $-0.141^{* * *}(0.032)$ & $-0.141^{* * *}(0.032)$ & $-0.141^{* * *}(0.032)$ & $-0.141^{* * *}(0.032$ \\
\hline Int. Goods Imp. $\left(\beta_{3}\right)$ & $-0.048^{* * *}(0.005)$ & $-0.048^{* * *}(0.005)$ & $-0.048^{* * *}(0.005)$ & $-0.048^{* * *}(0.005)$ & $-0.009(0.008)$ & $-0.010(0.008)$ & $-0.009(0.008)$ & $-0.009(0.008)$ \\
\hline Delta ER. $\left(\beta_{4}\right)$ & $-0.058^{* * *}(0.010)$ & $-0.062^{* * *}(0.011)$ & $-0.058^{* * *}(0.010)$ & $-0.063^{* * *}(0.011)$ & $-0.060 * * *(0.017)$ & $-0.060^{* * * *}(0.017)$ & $-0.060 * * *(0.017)$ & $-0.061 * * *(0.017)$ \\
\hline REER Vol. $\left(\beta_{5}\right)$ & $-0.222^{* * *}(0.076)$ & $-0.251^{* * *}(0.094)$ & $-0.213^{* * *}(0.078)$ & $-0.030(0.159)$ & $0.050(0.134)$ & $-0.041(0.151)$ & $0.044(0.135)$ & $0.093(0.181)$ \\
\hline DD*REER Vol. $\left(\beta_{6}\right)$ & & $-0.078(0.166)$ & & & & $0.325(0.253)$ & & \\
\hline SD*REER Vol. $\left(\beta_{7}\right)$ & & & $-0.169(0.287)$ & & & & $0.249(0.742)$ & \\
\hline MD*REER Vol. $\left(\beta_{8}\right)$ & & & & $-0.311^{*}(0.182)$ & & & & $-0.209(0.244)$ \\
\hline LD*REER Vol. $\left(\beta_{9}\right)$ & & & & $-0.393 *(0.204)$ & & & & $0.214(0.332)$ \\
\hline$\beta_{5}+\beta_{6}$ & & $-0.330 * *(0.151)$ & & & & $0.284(0.227)$ & & \\
\hline$\beta_{5}+\beta_{7}$ & & & $-0.381(0.281)$ & & & & $0.292(0.736)$ & \\
\hline$\beta_{5}+\beta_{8}$ & & & & $-0.340 * * *(0.110)$ & & & & $-0.116(0.193)$ \\
\hline$\beta_{5}+\beta_{9}$ & & & & $-0.423^{* * *}(0.143)$ & & & & $0.307(0.296)$ \\
\hline Observations & 39,931 & 39,931 & 39,931 & 39,931 & 16,783 & 16,783 & 16,783 & 16,783 \\
\hline Number of firms & 6069 & 6069 & 6069 & 6069 & 4023 & 4023 & 4023 & 4023 \\
\hline Hausman & 7.974 & 21.77 & 8.040 & 20.38 & 3.628 & 10.90 & 3.943 & 7.011 \\
\hline haus_p & 0.158 & 0.00278 & 0.235 & 0.0157 & 0.604 & 0.143 & 0.684 & 0.636 \\
\hline
\end{tabular}

This table displays the estimation results for the split-sample. In the first and the fifth columns no firm classification is included while in the subsequent columns, foreign market dependency (Dep), stock market status (Stock), and

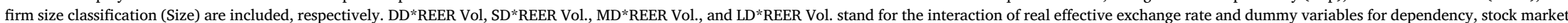
status, medium-size firms, and large-size firms, respectively. All firms are classified according to the number of employees as small (greater than 10 and less than 50), medium (greater than 49 and less than 250 ), and large (greater

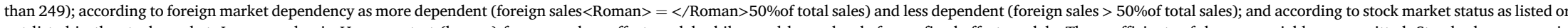

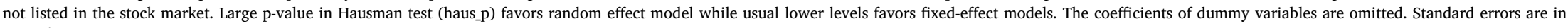
parentheses. ${ }^{* * *} \mathrm{p}<0.01,{ }^{* *} \mathrm{p}<0.05,{ }^{*} \mathrm{p}<0.1$ 
Table 8

Split-Sample: Mature vs. Non-Mature Firms.

\begin{tabular}{|c|c|c|c|c|c|c|c|c|}
\hline \multirow[t]{2}{*}{ Variables } & \multicolumn{4}{|l|}{ Matured Firms } & \multicolumn{4}{|l|}{ Not-matured Firms } \\
\hline & Basic & Dep & Stock & Size & Basic & Dep & Stock & Size \\
\hline External Demand $\left(\beta_{1}\right)$ & $0.262^{* * * *}(0.094)$ & $0.274 * *(0.106)$ & $0.258 * * *(0.094)$ & $0.260 * * *(0.094)$ & $0.285^{* *}(0.129)$ & $0.284 * *(0.129)$ & $0.286 * *(0.129)$ & $0.280 * *(0.129)$ \\
\hline Domestic Demand $\left(\beta_{2}\right)$ & $-0.161^{* * *}(0.021)$ & $-0.174^{* * *}(0.023)$ & $-0.161^{* * *}(0.021)$ & $-0.162^{* * *}(0.021)$ & $-0.110^{* * * *}(0.028)$ & $-0.110^{* * *}(0.028)$ & $-0.110^{* * * *}(0.028)$ & $-0.110^{* * * *}(0.028)$ \\
\hline Int. Goods Imp. $\left(\beta_{3}\right)$ & $-0.039 * * *(0.006)$ & $-0.038^{* * * *}(0.006)$ & $-0.038^{* * *}(0.006)$ & $-0.038^{* * *}(0.006)$ & $-0.035^{* * *}(0.007)$ & $-0.035 * * *(0.007)$ & $-0.035 * * *(0.007)$ & $-0.035^{* * *}(0.007)$ \\
\hline Delta ER. $\left(\beta_{4}\right)$ & $-0.041^{* * *}(0.012)$ & $-0.041^{* * *}(0.013)$ & $-0.041^{* * *}(0.012)$ & $-0.041^{* * *}(0.012)$ & $-0.091 * * *(0.016)$ & $-0.091 * * *(0.016)$ & $-0.091 * * *(0.016)$ & $-0.091^{* * *}(0.016)$ \\
\hline REER Vol. $\left(\beta_{5}\right)$ & $-0.148 *(0.089)$ & $-0.078(0.112)$ & $-0.122(0.092)$ & $0.141(0.160)$ & $-0.318^{* *}(0.127)$ & $-0.413 * * *(0.143)$ & $-0.331 * * *(0.127)$ & $-0.354 *(0.192)$ \\
\hline DD*REER Vol. $\left(\beta_{6}\right)$ & & $-0.194(0.201)$ & & & & $0.328(0.226)$ & & \\
\hline SD*REER Vol. $\left(\beta_{7}\right)$ & & & $-0.342(0.292)$ & & & & $0.643(0.748)$ & \\
\hline MD*REER Vol. $\left(\beta_{8}\right)$ & & & & $-0.384 *(0.189)$ & & & & $0.052(0.229)$ \\
\hline LD*REER Vol. $\left(\beta_{9}\right)$ & & & & $-0.398 *(0.208)$ & & & & $0.017(0.299)$ \\
\hline$\beta_{5}+\beta_{6}$ & & $-0.273(0.186)$ & & & & $-0.0849(0.204)$ & & \\
\hline$\beta_{5}+\beta_{7}$ & & & $-0.464(0.284)$ & & & & $0.312(0.744)$ & \\
\hline$\beta_{5}+\beta_{8}$ & & & & $-0.242 * *(0.120)$ & & & & $-0.302 *(0.164)$ \\
\hline$\beta_{5}+\beta_{9}$ & & & & $-0.256 *(0.149)$ & & & & $-0.338(0.252)$ \\
\hline Observations & 29,048 & 29,048 & 29,048 & 29,048 & 27,666 & 27,666 & 27,666 & 27,666 \\
\hline Number of firms & 5443 & 5443 & 5443 & 5443 & 7058 & 7058 & 7058 & 7058 \\
\hline Hausman & 6.601 & 12.21 & 6.972 & 14.45 & 15.23 & 15.49 & 15.55 & 26.22 \\
\hline haus_p & 0.252 & 0.0939 & 0.323 & 0.107 & 0.00944 & 0.0302 & 0.0164 & 0.00188 \\
\hline
\end{tabular}

This table displays the estimation results for the split-sample. In the first column no firm classification is included while in the subsequent columns, foreign market dependency (Dep), stock market status (Stock), and firm size

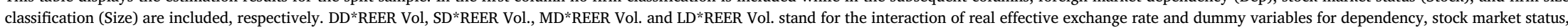

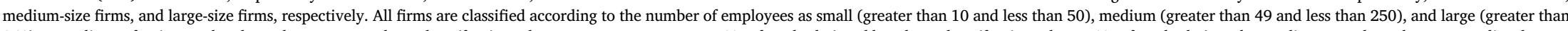

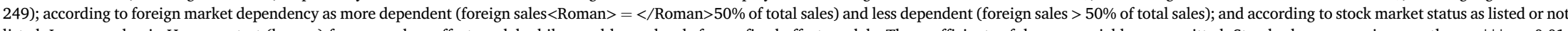

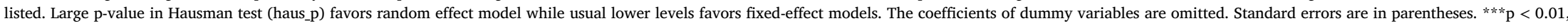
$* * \mathrm{p}<0.05, * \mathrm{p}<0.1$. 
Table 9

Baseline results with industry-fixed effects.

\begin{tabular}{|c|c|c|c|c|}
\hline Variables & Basic & Dep. & Stock & Size \\
\hline External Demand $\left(\beta_{1}\right)$ & $0.324 * * *(0.071)$ & $0.326 * * *(0.071)$ & $0.324 * * *(0.071)$ & $0.321 * * *(0.080)$ \\
\hline Domestic Demand $\left(\beta_{2}\right)$ & $-0.154 * * *(0.016)$ & $-0.154 * * *(0.016)$ & $-0.154 * * *(0.016)$ & $-0.147 * * *(0.018)$ \\
\hline Int. Goods Imp. $(\beta 3)$ & $-0.037 * * *(0.004)$ & $-0.037 * * *(0.004)$ & $-0.037 * * *(0.004)$ & $-0.039 * * *(0.005)$ \\
\hline Delta ER. $\left(\beta_{4}\right)$ & $-0.060 * * *(0.009)$ & $-0.060 * * *(0.009)$ & $-0.060 * * *(0.009)$ & $-0.060 * * *(0.010)$ \\
\hline REER Vol. $\left(\beta_{5}\right)$ & $-0.167 * *(0.068)$ & $-0.230 * * *(0.075)$ & $-0.160 * *(0.069)$ & $-0.049(0.130)$ \\
\hline DD*REER Vol. $\left(\beta_{6}\right)$ & & $0.260 *(0.134)$ & & \\
\hline SD*REER Vol. $\left(\beta_{7}\right)$ & & & $-0.153(0.272)$ & \\
\hline MD*REER Vol. $\left(\beta_{8}\right)$ & & & & $-0.258 *(0.153)$ \\
\hline LD*REER Vol. $\left(\beta_{9}\right)$ & & & & $-0.244(0.176)$ \\
\hline$\beta_{5}+\beta_{6}$ & & $-0.030(0.121)$ & & \\
\hline$\beta_{5}+\beta_{7}$ & & & $-0.314(0.268)$ & \\
\hline$\beta_{5}+\beta_{8}$ & & & & $-0.308^{* * *}(0.102)$ \\
\hline$\beta_{5}+\beta_{9}$ & & & & $-0.293^{* *}(0.134)$ \\
\hline Observations & 54,129 & 54,129 & 54,129 & 54,129 \\
\hline Number of firmid & 9802 & 9802 & 9802 & 9802 \\
\hline Hausman & 9.617 & 10.58 & 9.557 & 27.65 \\
\hline haus_p & 0.0868 & 0.158 & 0.145 & 0.00109 \\
\hline
\end{tabular}

This table displays the estimation results for the full-sample. In the first column no firm classification is included while in the subsequent columns, foreign market dependency (Dep), stock market status (Stock), and firm-size classification (Size) are included, respectively. DD*REER Vol, SD*REER Vol., MD*REER Vol., and LD*REER Vol. stand for the interaction of real effective exchange rate and dummy variables for dependency, stock market status, medium-size firms, and large-size firms, respectively. All firms are classified according to the number of employees as small (greater than 10 and less than 50), medium (greater than 49 and less than 250), and large (greater than 249); according to foreign market dependency as more dependent (foreign sales $<$ Roman $>=</$ Roman $>50 \%$ of total sales) and less dependent (foreign sales $>50 \%$ of total sales); and according to stock market status as listed or not listed in the stock market. Large p-value in Hausman test (haus_p) favors random effect model while usual lower levels favors fixed-effect models. The coefficients of dummy variables are omitted. Standard errors are in parentheses. $* * * \mathrm{p}<0.01, * * \mathrm{p}<0.05$, ${ }^{*} \mathrm{p}<0.1$.

policy makers should also take into consideration the heterogeneous response of firms to exchange rate volatility when designing any policy measure to promote export.

\section{References}

Arize, A. C. (1996). Real exchange-rate volatility and trade flows: The experience of eight European economies. International Review of Economics and Finance, 5(2), $187-205$.

Bahmani-Oskooee, M., \& Hegerty, S. W. (2007). Exchange rate volatility and trade flows: A review article. Journal of Economic Studies, 34(3), $211-255$.

Bailey, M. J., Tavlas, G. S., \& Ulan, M. (1986). Exchange-rate variability and trade performance: Evidence for the big seven industrial countries. Weltwirtschaftliches Archiv, 122(3), 466-477.

Barkoulas, J. T., Baum, C. F., \& Caglayan, M. (2002). Exchange rate effects on the volume and variability of trade flows. Journal of International Money and Finance, 21, 481-496.

Behmina, K. (2012). Exchange rate volatility and productivity growth: The role of liability dollarization. Open Economics Review, 23(3), 501-529.

Berman, N., Martin, P., \& Mayer, T. (2012). How do different exporters react to exchange rate changes? The Quarterly Journal of Economics, $127,437-492$.

Broll, U., \& Eckwert, B. (1999). Exchange rate volatility and international trade. Southern Economic Journal, 66(1), $178-185$.

Caglayan, M., \& Demir, F. (2014). Firm productivity, exchange rate movements, source of finance, and export orientation. World Development, 54, 204-219.

Chatterjee, A., Dix-Carneiro, R., \& Vichyanond, J. (2013). Multi-product firms and exchange rate fluctuations. American Economic Journal: Economic Policy, 5(2), 77-100.

Cheung, Y.-W., \& Sengupta, R. (2013). Impact of exchange rate movements on exports: An analysis of indian non-financial sector firms. Journal of International Money and Finance, 39, 231-245.

Chit, M. M., Rizov, M., \& Willenbockel, D. (2010). Exchange rate volatility and exports: New empirical evidence from the emerging East Asian economies. The World Economy, 33(2), 239-263.

Chowdhury, A. R. (1993). Does exchange rate volatility depress trade flows? Evidence from error- correction models. The Review of Economics and Statistics, 75(4), $700-706$.

Clark, P. B. (1973). Uncertainty, exchange risk, and the level of international trade. Economic Inquiry, 11(3), 302-313.

Clark, P. B., Natalia Tamirisa, a. S.-J. W., Sadikov, A., \& Zend, L. (2004). A new look at exchange rate volatility and trade flows. IMF Occasional Paper 235 (pp. 1-65).

Cushman, D. O. (1983). The effects of real exchange rate risk on international trade. Journal of International Economics, 15(1), 45-63.

Dekle, R., \& Ryoo, H. H. (2007). Exchange rate fluctuations, financing constraints, hedging, and exports: Evidence from firm level data. Journal of International Financial Markets, Institutions and Money, 17(5), 437-451.

Demirhan, A. A. (2015). To be exporter or not to be exporter? Entry exit dynamics of Turkish manufacturing firms. Empirical Economics, 51(1), 181-200.

Ethier, W. (1973). International trade and the forward exchange market. American Economic Review, 63(3), 494-503.

Franke, G. (1991). Exchange rate volatility and international trading strategy. Journal of International Money and Finance, 10, $292-307$.

Gagnon, J. E. (1993). Exchange rate variability and the level of international trade. Journal of International Economics, 34, $269-287$.

Grauwe, P. D. (1988). Exchange rate variability and the slowdown in growth of international trade. IMF Staff Papers, 35(1), 63-84.

Greenaway, D., Kneller, R., \& Zhang, X. (2010). Exchange rate uncertainty and export decisions in the UK. Journal of Economic Integration, 25(4), 734-753.

Guillou, S. (2008). Exports and exchange rate: A firm level investigation. OFCE WP 2008-02 (pp. 1-24).

Hericourt, J., \& Nedoncelle, C. (2015). How multi-destination firms shape the effect of exchange rate volatility on trade: micro evidence and aggregate implications. CEPII Working Paper 2016-05 (pp. 1-46).

Hericourt, J., \& Poncet, S. (2013). Exchange rate volatility, financial constraints, and trade: Empirical evidence from Chinese firms. World Bank Economic Review, 29(2), $550-578$.

Hooper, P., \& Kohlhagen, S. W. (1978). The effect of exchange rate uncertainty on the prices and volume of international trade. Journal of International Economics, 8, 483-511.

Kandilov, I., \& Leblebicioglu, A. (2014). Exchange rate volatility and exports: The case of Colombia. In O. Morissey, R. Lopez, \& K. Sharma (Eds.), Handbook of trade and development. Edward Elgar Publishing.

Kenen, P. B., \& Rodrik, D. (1986). Measuring and analyzing the effects of short-term volatility in real exchange rates. The Review of Economics and Statistics, 68(2), $311-315$. 
Klein, M. W. (1990). Sectoral effects of exchange rate volatility on United Stated exports. Journal of International Money and Finance, 9, $299-308$.

Lassmann, A. (2013). Exchange rate transmission and export activity at the firm level. KOF WP 331 (pp. 1-37).

Li, H., Ma, H., \& Xu, Y. (2015). How do exchange rate movements affect Chinese exports? A firm-level investigation. Journal of International Economics, 97(1), 148-161.

McKenzei, M. D. (1999). The impact of exchange rate volatility on international trade flows. Journal of Economic Surveys, 13(1), 71-106.

Minetti, R., \& Zhu, S. C. (2011). Credit constraints and firm export: Microeconomic evidence from Italy. Journal of International Economics, 83(2), 109-125.

Rahman, S., \& Serletis, A. (2009). The effects of exchange rate uncertainty on exports. Journal of Macroeconomics, 31, $500-507$.

Sauer, C., \& Bohara, A. K. (2001). Exchange rate volatility and exports: Regional differences between developing and industrialized countries. Review of International Economics, 9(1), 133-152.

Saygili, S., Cihan, C., Yalcin, C., \& Brand, T. H. (2012). Turkiye imalat sanayiinde ithal Girdi Kullanimi. Iktisat Isletme Ve Finans, $321,09-38$.

Sercu, P., \& Vanhulle, C. (1992). Exchange rate volatility, international trade, and the value of exporting firms. Journal of Banking and Finance, 16, 155-182.

Solakoglu, M. N. (2010). Exchange rate exposure and real exports. Applied Economics Letters, 17(5), 457-462.

Solakoglu, M. N., Solakoglu, E. G., \& Demirag, T. (2008). Exchange rate volatility and exports: A firm-level analysis. Applied Economics, 40, $921-929$.

Tenreyno, S. (2007). On the trade impact of nominal exchange rate volatility. Journal of Development Economics, 82(2), 485-508. 